\title{
Cell Lysis Cryptic Growth Method Using Ozonation for Excess Sludge Minimization: A Review
}

\author{
Navalakha Aparna \\ Department of Environmental Management, LD College of Engineering, Ahmedabad, Gujarat, India \\ "Corresponding author: Navalakha Aparna A, Department of Environmental Management, LD College of Engineering, Ahmedabad, Gujarat, India, Tel: \\ +918160218388; E-mail: aparna.navalakha@gmail.com \\ Received: December 15, 2017; Accepted: December 29, 2017; Published: January 08, 2018 \\ Copyright: (c) 2018 Aparna N. This is an open-access article distributed under the terms of the Creative Commons Attribution License, which permits unrestricted use, \\ distribution, and reproduction in any medium, provided the original author and source are credited.

\begin{abstract}
In any wastewater treatment plant large amount of sludge generation is major issue. The final disposal of the sludge cost almost $60 \%$ of total operational cost of treatment plant. In addition to this, it is necessary to meet today's stringent pollution control norms, thus finding methods to minimize excess of sludge is of growing interest. The paper mainly focuses on sludge reduction based on cell lysis cryptic growth method using ozonation for both in wastewater line and sludge line.
\end{abstract}

Keywords: Lysis cryptic growth; Ozonation; Sludge reduction; Dewatering; Setteability; Filterability

\section{Introduction}

In Waste Water Treatment Plant (WWTP) sludge can be produced in two ways; primary which is produced by settleable solids removed from influent wastewater in primary settling; and secondary which is produced by biological process such as activated sludge process. But among all sludge secondary sludge or excess sludge is of great concern because, during the biological treatment of industrial effluent wastewater, in addition to cell biomass, a large amount of nonbiodegradable (inert) solids in particulate form, incoming with the influent raw wastewater, contributes significantly to sludge production. Besides this secondary sludge is difficult to dewater because of high amount of bound water content. The final disposal of this sludge cost $60 \%$ of total operational cost of treatment plant. So, considering environmental burden and high expense, finding methods which minimize sludge production is of growing interest. There are many techniques available for reduction of sludge for example lysis cryptic growth method, metabolic uncoupler, endogeneous metabolism, microbial predation, hydrothermal oxidation but the paper mainly focuses on reviewing lysis cryptic growth method. The term lysis means breakdown of cell wall or cellular membrane due to some external force and the term cryptic growth means survival of remaining cells on contents lysed from dead cell. When microbial cell undergo lysis or death, the cell contents are released into external environment and provide autochthonous substrate that contributes to the organic loading. Now the few remaining cell will grow either using this autochthonous substrate or using substrate which is already present in wastewater therefore this type of growth is termed as cryptic growth. However once lysed, it becomes easy for the living cells to biodegrade the lysed cells, therefore lysis is the rate-limiting step of lysis-cryptic growth, and an increase of the lysis efficiency can therefore lead to an overall reduction of sludge production (Figures 1 and 2).

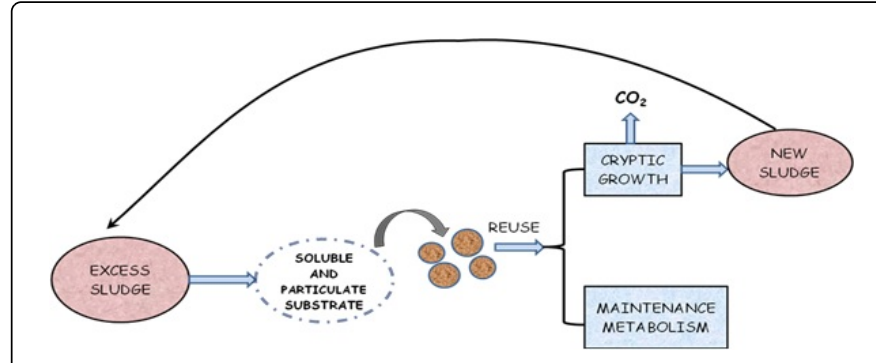

Figure 1: Schematics of cell lysis cryptic growth.

The cell lysis cryptic growth technique can be used in both wastewater handling line and sludge handling line. The figure shows the possible location of lysis cryptic growth method in WWTP.

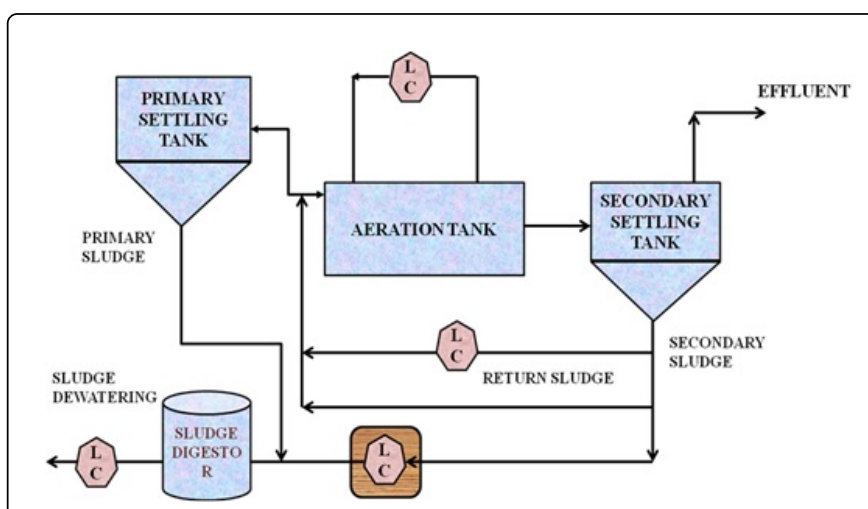

Figure 2: Possible location for cell lysis and cryptic growth (LC) techniques.

The objective of this paper is to critically review current and emerging approaches of sludge reduction based on lysis cryptic growth method using ozonation. 


\section{Mechanism of sludge reduction by lysis cryptic growth method using ozonation}

Applying ozone on activated sludge facilitate sludge solubilisation followed by "cryptic growth". During ozonation of sludge, biomass degradation could be described as two main mechanisms:

1. Disintegration due to cell destruction of suspended solids in waste sludge. (converted into soluble intermediate organic products through cell lysis and hydrolysis)

2. Mineralization due to subsequent oxidation of soluble organic matter to carbon dioxide. Sludge reduction could be accomplished by these two products, disintegrated solids and mineralized material. (Directly oxidized into $\mathrm{CO}_{2}$ and $\mathrm{H}_{2} \mathrm{O}$ )

3. Remaining sludge-So here "one-third" of biomass will be mineralized, thereby biomass is decreased to "two thirds".

\section{Ozonation in wastewater line}

\section{Lab scale ozonation:}

- Yasui et al. studied ozone treatment of excess sludge followed by recirculation of the treated sludge into the bioreactor. They have carried out continuous flow experiment in which sludge to be ozonated was drawn continuously from aeration tank and ozonated by batch treatment. Ten runs of recirculation treatment were carried out for a period of 6 weeks [1].

- Albuquerque studied ozonation in both continuous and discontinuous bench scale model [2]. The experiments were conducted in a glass reactor of $2 \mathrm{~L}$ with sludge from the recycling line. The gas (pure $\mathrm{O}_{2}$ and $\mathrm{O}_{3}$ ) flow rate was kept constant but the ozone concentration in the gas stream and the reaction time varied at three levels (12, 30 and $50 \mathrm{mg} / \mathrm{L})$ and $(5,10$ and $15 \mathrm{~min})$, respectively. Continuous experiments were conducted in a bench scale activated sludge unit composed of an aerated reactor $(5 \mathrm{~L})$ and a secondary clarifier ( $1 \mathrm{~L})$. Several operation runs were performed varying the percentage of ozonated sludge in the recycling stream (10 and $20 \%$ on a volumetric basis) and the ratio between recycle and influent flow rates (1/3 and 2/3).

- Two lab scale activated sludge system was operated in parallel by Huysmans [3], in which one was used as a control system and other as treatment system where part of ozonated sludge was ozonated. Each lab scale plant was operated as a Sequencing Batch Reactor (SBR). The reactor contained an aeration device and a mechanical stirrer. Experiment consisted following steps:

(1) Filling; $30 \mathrm{~min}$,

(2) Anoxic phase; $4 \mathrm{~h}$,

(3) Aerobic phase; $4 \mathrm{~h}$

(4) Anoxic phase; $1 \mathrm{~h}$,

(5) Aerobic phase; $4 \mathrm{~h}$,

(6) settling: $1 \mathrm{~h}$ and,

(7) Withdrawing effluent; $30 \mathrm{~min}$.

\section{Pilot scale ozonation}

- Pilot scale ozonation model was developed by Ahn [4] at Gwangju wastewater treatment plant in Gyeonggi-do province, Korea. The system was designed for a waste activated sludge capacity of around $0.2 \mathrm{~m}^{3} / \mathrm{d}$. The system was one of the sequencing batch activated sludge processes, with continuous feeding. The operating cycle consisted of a $30 \mathrm{~min}$ anoxic settling phase, a $30 \mathrm{~min}$ anaerobic decanting phase, and a $60 \mathrm{~min}$ aerobic phase with continuous feeding of actual domestic wastewater into the bottom of the bioreactor. The system was designed with a Hydraulic Retention Time (HRT) of 16.5 hours. Ozone gas flow-rate of 1 $\mathrm{m}^{3} / \mathrm{hr}$ at an ozone concentration of $150 \mathrm{~g} \mathrm{O}_{3} / \mathrm{m}^{3}$ was supplied in the reactor.

\section{Full scale ozonation}

- Gardoni developed the system operating waste sludge minimization by means of a full-scale, plug-flow, short HRT ozone contactor [5]. A $20 \%$ fraction of the recycling stream was ozonated in a plug-flow contactor with a very low contact time (few seconds) with an ozone solubilization efficiency of more than $90 \%$.

\section{Ozonation in sludge handling line}

\section{Lab scale ozonation:}

- Two, 2-L bench-scale, batch digesters were operated in parallel for 30 days by Mines et al. [6]. One was sparged with air and the other ozone. Each digester contained 1.7-L of WAS (Waste Activated Sludge). The aerobic digester was supplied with air at 2.7 liters per minute $(\mathrm{Lpm})$ or $810 \mathrm{mg} \mathrm{O}_{2} / \mathrm{min}$. The carrier gas low rate to the ozonated digester was maintained at a constant of $6.5 \mathrm{Lpm}$ or 0.88 $\mathrm{mg} \mathrm{O}_{3} / \mathrm{min}$ in Phase II. The air low rate to the aerobic digester was increased from 2.7 to $4.0 \mathrm{Lpm}$ or $1,200 \mathrm{mg} \mathrm{O}_{2} / \mathrm{min}$. The ozone feed rate during Phase II was reduced from 6.5 to $3.25 \mathrm{Lpm}$ or $0.44 \mathrm{mg}$ $\mathrm{O}_{3} / \mathrm{min}$.

- Richard et al. conducted bench-scale ozonation study on waste activated sludge (WAS) in a $10-\mathrm{L}$, clear PVC, semi-batch, bubble column reactor [7]. Two separate runs were performed on 5-L samples of WAS obtained from the Rocky Creek Wastewater Treatment Plant (WWTP) in Macon, Georgia. Ozone was sparged through a porous diffuser at an application rate of $0.0525 \mathrm{mg} \mathrm{O}_{3}$ $\min ^{-1}$ at contact times of 9 days and 12 days, respectively, during Runs \#1 and \#2.

- Moussavi developed the system consist annular glass tube with the total volume of $2 \mathrm{~L}$ that in each run $1.5 \mathrm{~L}$ sludge was poured into it and ozonated [8]. The experiment carried out at different batch runs consisted of 3 several ozone doses between 0.125 to $2 \mathrm{~g} \mathrm{O}_{3} / \mathrm{g}$ TS. Ozone-laden gas flow rate was fixed at $1 \mathrm{~L} / \mathrm{min}$ in which ozone inlet concentration was about $0.45 \mathrm{~g} / \mathrm{h}$.

- Akhlaque and Farooq performed ozonation in a glass batch reactor with a capacity of $20 \mathrm{~L}$. It was $14 \mathrm{in}$. (356 mm) in diameter and 20 in. $(508 \mathrm{~mm})$ long [9]. Ozone gas was supplied at the bottom of the reactor through a medium porosity, fritted glass diffuser. Unused gas was exhausted into the atmosphere through a hood from the top of the reactor. Sludge samples were ozonated continuously in the reactor for 30,60 and 120 minutes periods.

\section{Pilot scale ozonation}

- A pilot-scale ozone reactor for sludge treatment with a capacity of $1 \mathrm{~m}^{3}$ has been established at Gwangju wastewater treatment plant in Gyeonggi province, Korea by Park [10]. The SS concentration of waste activated sludge was at around $8 \mathrm{~g} / \mathrm{L}$ to $12 \mathrm{~g} / \mathrm{L}$ with $73 \%$ of VSS. The waste activated sludge was ozonized in a cylindrical shape column reactor with ozone flowrate of $1 \mathrm{~m}^{3} / \mathrm{hr}$ and ozone concentration of $150 \mathrm{~g} \mathrm{O}_{3} / \mathrm{m}^{3}$. 


\section{Sludge after ozonation}

Mass and volume reduction: Sludge volume and mass reduction is mainly depend on the reduction of all types of solid reduction in sludge including Total Solids (TS), Total suspended solids(TSS), Volatile suspended solids (VSS), Dissolved Solids (DS). At different ozone dose percent destruction of solids was observed by some researchers and some of their results are shown below:

- Ahn concluded that at an ozone dose of $0.2 \mathrm{~g} \mathrm{O}_{3} / \mathrm{g}$ DS, the mineralization, carbon source and biosolids residual were 5\%, 50\% and $45 \%$, respectively, and the composition at $0.5 \mathrm{~g} \mathrm{O}_{3} / \mathrm{g}$ DS changed to $20 \%, 46 \%$ and $34 \%$, respectively. In other words, a significant mass reduction was achieved as the ozone dose was increased while the carbon source generation remained the same [4].

- Yasui reported that nearly $35 \%$ of treated biomass was mineralized biologically and reduction efficiency was proportional to mass to be treated [1].

- Albuquerque concluded that in discontinuous experiments a concentration of $30 \mathrm{mg} \mathrm{O} / \mathrm{L}$, applied for 10 or $15 \mathrm{~min}$, was sufficient to promote partial degradation of the biological sludge and in continuous experiment sludge production reduction was comprised between 14 and 39\% [5].

- Gardoni observed sludge production yield $\left(\mathrm{Y}_{\mathrm{obs}}\right)$ decreased from an average value of 0.435 during the control period to 0.36 $\mathrm{kgCOD}_{\text {biomass }}\left(\mathrm{kgCOD}_{\text {substrate }}\right)-1$ during the ozonation period, corresponding to a $17 \%$ net reduction [8].

- Huysmans used ozone dosing rate of $0.05 \mathrm{~g} \mathrm{O}_{3} / \mathrm{g} \mathrm{SS}_{\text {removed. At this }}$ dose a mean SS decrease of $49 \%$ of the excess sludge was obtained. At average ozone dose of $0.019 \mathrm{~g} \mathrm{O}_{3} / \mathrm{g} \mathrm{SS}_{\text {ozonated }} 50 \%$ sludge decrease was obtained compared to control [6].

- Moussavi observed that mass reduction of suspended solids in sludge increased with the increasing the rate of ozonation in where the attained destruction efficiency of TSS for ozone doses of 0.125 , $03.25,0.5,1$ and $2 \mathrm{~g} \mathrm{O}_{3} / \mathrm{g}$ TS was $15.4 \%, 34.3 \%, 56.5 \%, 70.1 \%$ and $80.7 \%$, respectively [8]. The greater the ozone dose, the higher reduction in suspended solids was obtained.

- According to Mines et al. [6] ozonation was more effective at reducing TS than aerobic digestion; 50 and 56\% TS removals were observed compared to 23 and $35 \%$ for aerobic digestion and ozonation was also more effective at reducing VS than aerobic digestion; 57 and $74 \%$ VS removals were observed compared to 40 and $42 \%$ for aerobic digestion.

- Total solids removals of 50 and $95 \%$ Volatile suspended solids removals of 45 and $99 \%$ was observed by Mines and Lackey [7] at an application rate of $0.0525 \mathrm{mg} \mathrm{O}_{3} / \mathrm{min}$ and contact times of 9 days and 12 days respectively.

- According to Park [10] the degree of degradation of suspended solids based on residual solids, that contribute to final sludge mass reduction, at ozone dose of $0.1 \mathrm{~g} \mathrm{O}_{3} / \mathrm{gDS}, 0.2 \mathrm{~g} \mathrm{O}_{3} / \mathrm{gDS}$, and $0.5 \mathrm{~g}$ $\mathrm{O}_{3} / \mathrm{gDS}$ was found to be $45 \%, 55 \%$, and $65 \%$, respectively [10].

\section{Settling properties of ozonated sludge}

Settleability of sludge is a key parameter in operation of sludge handling facilities. The settleability can be estimated by measuring SV30 (\% of sludge volume after 30 minutes settling). Settling properties observation by few researchers is given below:
- Park observed that initial settling velocity, increased rapidly to an ozone dose of $0.5 \mathrm{gO}_{3} / \mathrm{gDS}$ and then slowly increased at further ozone dose [10]. SV30 was extremely improved by ozonation up to dose of $0.2 \mathrm{gO}_{3} / \mathrm{gDS}$ and then gradient of settling curve was reduced [10].

- Moussavi concluded that ozonation drastically improved the sedimentation properties of the sludge particularly in doses lower than $1 \mathrm{gO}_{3} / \mathrm{g}$ TS in where settlable solids of the sludge decreased from $950 \mathrm{~mL} / \mathrm{L}$ (before ozonation) to $234 \mathrm{~mL} / \mathrm{L}$ [8]. When the dose of ozone was increased to $2 \mathrm{gO}_{3} / \mathrm{g}$ TS the quantity of settlable solids reduced to $110 \mathrm{gO}_{3} / \mathrm{g}$ TS.

- Sludge settleability was greatly improved by ozonation above $0.2 \mathrm{~g}$ $\mathrm{O}_{3} / \mathrm{g}$ DS [4].

- The ozonated sludge settled more rapidly than did the aerated sludge and resulted in a more compact layer of sludge at the bottom of the beaker [6].

- Akhlaque and Farooq observed that improvement in settling rate of the sludge for $0,30,60$ and 120 minutes ozonated samples upto 30 hours, respectively [9].

- During Run \#1, the SVI increased slightly from day 1 to day 2 and then decreased before increasing from day 7 to day 9. During Run \#2, SVI dropped significantly from 278 to around $43 \mathrm{~mL} / \mathrm{g}$ before increasing again as ozone contact time was increased [7].

\section{Dewatering properties of ozonated sludge}

Sludge dewaterability was measured by various researchers using different methods for dewatering and their observation is concluded in below points:

- Park used a pressure filter operated at a pressure of $300 \mathrm{kPa}$ for dewatering and observed that compared to raw waste activated sludge the cake solid concentration was reached to about $15-20 \%$ due to ozonation [10].

- Gravity draining of sludge in sand column improve characteristics in 30 min ozonated sample for return activated sludge [9].

- The decrease of bound water after ozone treatment indicates that the release of the interstitial water trapped inside cells or flocs is responsible for observed decrease of water content of dewatered cake.

- The dewaterability continuously improved in proportion to ozone dose, i.e., the $\mathrm{Ck}$ (cake moisture content) value continuously decreased up to $55 \%[4]$.

\section{Filterability of ozonated sludge}

- Sludge filtration property can be measured by Surface Resistance to Filtration (SRF) test.

- The filtration of sludge is related to the ozone dose. The specific resistance to filtration (SRF) value rapidly increased at an ozone dose up to $0.2 \mathrm{gO}_{3} / \mathrm{g}$ TS and then decreased dramatically at a dose of $0.2 \mathrm{gO}_{3} / \mathrm{g}$ TS.

- $\mathrm{SRF}$ value rapidly increased with ozone doses up to $0.2 \mathrm{~g} \mathrm{O}_{3} / \mathrm{g}$ DS, and then decreased dramatically at an ozone dose of $0.5 \mathrm{~g} \mathrm{O}_{3} / \mathrm{g}$ DS and above. This result was consistent with decrease in the microparticle fraction at a relatively high ozone dose [4].

- For ozonized sludge, the SRF increased sharply from $2 \times 10^{14} \mathrm{~m} / \mathrm{kg}$ to $38 \times 10^{14} \mathrm{~m} / \mathrm{kg}$ at a dose of $0.3 \mathrm{gO}_{3} / \mathrm{gSS}$, and then the SRF decrased significantly to $6 \times 10^{14} \mathrm{~m} / \mathrm{kg}$ at a dose of $0.6 \mathrm{gO}_{3} / \mathrm{gSS}$. 


\section{Conclusion}

This review showed that ozonation is far most advantageous method among all lysis cryptic growth method because it is compact, clean and powerful technique. Ozonation of RAS can result in a considerable reduction of excess sludge (up to $100 \%$ ), removal. In addition to sludge reduction ozonation also cause positive effect on settleability, dewaterability and filterability. It can be adopted successfully in bench scale as well as pilot scale plant. Ozonation can reduce both mass and volume of sludge. Ozonation drastically improved the sedimentation properties of the sludge which results in improved settling. After ozonation, release of the interstitial water trapped inside cells or flocs is responsible for decrease of water content and increase of solid content of dewatered cake. Ozonation will increase filterability upto certain dose but after that it will cause negative effect on filterability. So overall lysis cryptic growth with ozonation seems to be promising technology for sludge reduction but further research must be focused on other aspects like effluent quality after treatment, microbial activity during and after ozonation and economical viewpoint.

\section{References}

1. Yasui H, Shibata M (1994) An innovative approach to reduce excess sludge production in the activated sludge process. Water Sci Technol 30: 11-20.
2. Albuquerque JS, Domingos JC, Sant'Anna GL, Dezotti M (2008) Application of ozonation to reduce biological sludge production in an industrial wastewater treatment plant. Water Sci Technol 58: 1971-1976.

3. Huysmans A, Weemaes M, Fonseca PA, Verstraete W (2001) Ozonation of activated sludge in the recycle stream. J Chem Technol Biotechnol 76: 321-324.

4. Ahn KH, Park KY, Maeng SK, Hwang JH, Lee JW, et al. (2002) Ozonation of wastewater sludge for reduction and recycling. Water Sci Technol 46: 71-77.

5. Gardoni D, Ficara E, Fornarelli R, Parolini M, Canziani R (2011) Longterm effects of the ozonation of the sludge recycling stream on excess sludge reduction and biomass activity at full-scale. Water Sci Technol 63: 2032-2038.

6. Mines RO, Northenor CB, Murchison M (2008) Oxidation and ozonation of waste activated sludge. J Environ Sci Heal 43: 610-618.

7. Mines RO, Lackey LW (2009) Bench-scale ozonation study of waste activated sludge. J Environ Sci Heal 44: 38-47.

8. Moussavi G, Asilian H, Jamal A (2008) Effect of Ozonation on Reduction of Volume and Mass of Waste Activated Sludge. J App Sci 4: 122-127.

9. Akhlaque S, Farooq S (1982) Effects of ozonation on dewatering, drying and settling characteristics of biological sludges. Environ Technol Lett 3: 9-18.

10. Park KY, Ahn KH, Maeng SK, Hwang JH, Kwon JH (2003) Feasibility of sludge ozonation for stabilization and conditioning. Ozone Sci Eng 25: 73-80. 